Corresponding Author:

Arida Susilowati

arida_iswanto@yahoo.co.id

Received: 19 February 2019

Accepted: 5 March 2019

Published: 16 April 2019

Publishing services provided by Knowledge E

(c) Arida Susilowati et al. This article is distributed under the terms of the Creative Commons

Attribution License, which

permits unrestricted use and

redistribution provided that the

original author and source are credited.

Selection and Peer-review under the responsibility of the ICBSA Conference Committee.

\section{Optimizing Genomic DNA Isolation and PCR Amplification For Pasak Bumi (Eurycoma longifolia)}

\author{
Arida Susilowati ${ }^{1,2}$, Henti Hendalastuti Rachmat ${ }^{3}$, Ahmad Baiquni Rangkuti ${ }^{1}$, \\ Deni Elfiati ${ }^{1}$, and Ami Ambarwati ${ }^{1}$ \\ ${ }^{1}$ Faculty of Forestry, Universitas Sumatera Utara. JIn Tridharma Ujung No 1, Kampus USU. Medan. \\ North Sumatra, 20155, Indonesia \\ ${ }^{2}$ Mangrove and Bio-resources Group. Center of Excellence for Natural Resources Based \\ Technology, Universitas Sumatera Utara. Medan. North Sumatra, 20155, Indonesia \\ ${ }^{3}$ Forest Research, Development and Inovation Agency. Ministry of Environment and Forestry. \\ Jln Raya Gunung Batu. Bogor, West Java
}

\section{Abstract}

Pasak bumi (Eurycoma longifolia Jack) is a shrubs growing wildly in the forests of Southeast Asia and widely used throughout the region because of its medicinal properties. Uncontrolled harvesting of wild-grown trees has led to rapid decrease of it natural populations, as well as causing a potential decrease in genetic diversity. Information about population genetic of pasak bumi still not determined yet, including the optimal DNA isolation and it reference marker. Therefore, our research was conducted to get information about optimal DNA isolation using CTAB methods and reference marker for population genetic study. DNA isolation was conducted through CTAB (Cetyl Trimetyl Ammonium Bromide) method. The yield DNA was PCR amplified using four barcoding standard marker those were ITS, matK, rbcL and trnL-trnF. The result showed that CTAB method was able to yield good quality DNA and 30\% dilution produced the best band. The trnL-trnF primer was able to amplified DNA of pasak bumi with $50^{\circ} \mathrm{C}$ annealing temperature, $r b c \mathrm{~L}$ with $55^{\circ} \mathrm{C}$ annealing temperature and ITS with $50^{\circ} \mathrm{C}$ annealing temperature. While the matK primer failed to amplified.

Keywords: DNA, genetic, isolation, amplification, pasak bumi

\section{Introduction}

Pasak bumi is famous medicinal plant in Indonesia. Pharmacological testing found the utilization of pasak bumi for anti-cancer [1], anti-malarial [2], anti-leukemia, anti-HIV [3], and aphrodisiacs [4]. The increasing of illegal harvesting, low natural regeneration and limited habitat preference in Sumatra and Kalimantan Island, causing the population conditions to decline. The natural germination percentage of this species is very low and requires a long time due to immature embryos at the time of dispersal [5]. Based on this considerations, Indonesian government since 2006 has listed the species into 
protected plant species. Genetic based conservation effort is needed to avoid species extinction from its wild habitat.

Information about molecular aspects of pasak bumi in Indonesia has been lacking. Previous research showed that pasak bumi maintain a moderate diversity $[6,7]$. Research on population genetics, DNA isolation processes and reference markers have also been limited. Research on DNA isolation and reference markers that can be used for further molecular analysis therefore needed for underlying basic knowledge in establishing appropriate conservation effort of the species.

DNA quality was one of the significant factor to determine the successfulness of molecular analysis. The high quality and purity of DNA stock will be affecting amplification of DNA on Polymerase Chain Reaction (PCR) process. Different with herbaceous plant, many part of trees containing of some DNA inhibitor such as polysaccharides, tannin, phenol and other secondary metabolites substances. These substances will inhabit DNA polymerase activity during PCR process [8].

Many different methods and technologies are available for the isolation of genomic DNA. In general, all methods involve disruption and lysis of the starting material followed by the removal of proteins and other contaminants and finally recovery of the DNA. CTAB (Cetyl Trimetyl Ammonium Bromide) method was used in this research. The method was generally used as choice for extraction of plant material with high polysaccharides and other inhibitory substances and has been used successfully for some higher plant and forest trees [9].

Internal Transcribed Spacer (ITS), maturase K (matK), trnL-trnF intergenic spacer and ribulose-1, 5-bisphosphate carboxylase oxygenase $(r b c L)$ was used in this research as standard marker for barcoding. The utilization of this three chloroplast DNA regions and spacer due to the high ability for determining plant species and producing high quality sequences [10]. The chloroplast genome also non recombining inheritance unit, single, have stable structure and primarily maternally in angiosperms [11, 12]. ITS coding regions have a critical role in the development of functional ribosomal RNA, with sequence variations among species showing promise as signature regions for molecular assays. Therefore, the objective of this research were optimal DNA isolation using CTAB methods and reference marker for further used in various molecular studies. 


\section{Material and Methods}

Ten fresh leave samples of pasak bumi were collected from Padang Lawas, North Sumatra. All samples stored in plastic bags containing silica gel and kept at room temperature until DNA extraction. CTAB method [13] was using for extracting total genomic DNA of pasak bumi leaf. To check of DNA quality solution stock, $5 \mu \mathrm{L}$ of DNA combined with $2 \mu \mathrm{L}$ of loading dye was running on $5 \%$ agarose gel using horizontal electrophoresis. For marker, 1000 and 5000 bp DNA ladder from SERVA DNA was used. The gels were stained with GelRed. Visualization of DNA product was conducted by using an ultraviolet light chamber (GeIDoc-It, UVP Imaging system).

Four barcoding standard marker those were ITS, mat $\mathrm{K}, r b c \mathrm{~L}$ and $\operatorname{trnL}$-trnF were used in this research (Table 1). The PCR was performed using solution containing $20 \mu$ (10 ng) genomic DNA pasak bumi, forward and reverse primer (5 p mol) and Go Taq ${ }^{\circledR}$ Hot Start Colourless Master Mix (10 $\mu$ l).

TABLE 1: Primer used in this study.

\begin{tabular}{l|l} 
No & Primer \\
1 & rbcLa-f \\
& rbcLa-r \\
\hline 2 & trnLc-f \\
& trnLf-r \\
\hline 3 & ITS 1 \\
\hline 4 & matK-1RKIM-f \\
& matK-1RKIM-r
\end{tabular}

Sequence
ATGTCACCACAAACAGAGACTAAAGC
GTAAAATCAAGTCCACCRCG
CGAAATCGGTAGACGCTACG
ATTTGAACTGGTGACACGAG
TCCGTAGGTGAACCTGCGG
ACCCAGTCCATCTGGAATCTTGGTTC
CGT ACA GTA CTT TTG TGT TTA CGAG

\begin{tabular}{|c|c|c|}
\hline References & Length & $t_{m}$ \\
\hline$[14]$ & $1289 \mathrm{bp}$ & $56^{\circ} \mathrm{C}$ \\
\hline$[14]$ & $1289 \mathrm{bp}$ & $56^{\circ} \mathrm{C}$ \\
\hline$[15]$ & $447 \mathrm{bp}$ & $50^{\circ} \mathrm{C}$ \\
\hline$[15]$ & $447 \mathrm{bp}$ & $50^{\circ} \mathrm{C}$ \\
\hline$[16]$ & $565-613 \mathrm{bp}$ & $50^{\circ} \mathrm{C}$ \\
\hline$[17]$ & $889 \mathrm{bp}$ & $50^{\circ} \mathrm{C}$ \\
\hline$[17]$ & $889 \mathrm{bp}$ & $50^{\circ} \mathrm{C}$ \\
\hline
\end{tabular}

The process of PCR consists of four step those are initial denaturation, denaturation, annealing and final extension. Initial denaturation was conducted at temperature $95^{\circ} \mathrm{C}$ for $2 \mathrm{~min}$. Denaturation step was perform at temperature $95^{\circ} \mathrm{C}$ for $1 \mathrm{~min}$, while annealing step was performed at temperature $52^{\circ} \mathrm{C}$ followed by polymerization at $72^{\circ} \mathrm{C}$ for $2 \mathrm{~min}$. The last step was final extension which performed at $72^{\circ} \mathrm{C}$ for $7 \mathrm{~min}$.

\section{Result and discussion}

\subsection{DNA isolation}

DNA isolation methods should ideally be straightforward, quick, efficient, and reproducible while minimizing the potential for cross-contamination. It should also be suitable for extracting multiple samples and generate minimal risk for the operator. Safety, time 
and costs are also main considerations [18]. Some species are characterized by a high content of tannins, alkaloids, and phenols in their leaves. These secondary metabolites are released during DNA extraction and influence polymerase chain reaction. It became problem of DNA extraction for some tree species [19].

Leaf of pasak bumi contain some phenolic and terpenoid compound [20]. Polyphenols released from the vacuoles during the cell lysis process are oxidized by cellular oxidases and undergo irreversible interactions with nucleic acids causing browning of the DNA [21]. Residual polyphenols, polysaccharides and secondary metabolites interfere with the activity of several biological enzymes like polymerases, ligases and restriction endonucleases [22]. To avoid the oxidative effect of polyphenols, the extraction buffer should contain anti-oxidant agents, such as PVP (polyvinylpyrrolidone), BSA (bovine serum albumin), or $\beta$-mercaptoethanol [23].

High quality DNA is characterized by DNA of high molecular weight, without contaminating substances, such as proteins, polysaccharides, phenolics, or other secondary metabolites. Result of DNA isolation using CTAB method showed that this method gave better DNA yield in terms of quality and quantity (Fig. 1).

Based on our research modified CTAB (Cetyl trimethyl ammonium bromide) protocol enables to produce good DNA yield. CTAB able to produce high quality genomic DNA amenable to RAPD (Random amplified Polymorphic DNA), restriction digestion, and amplification of plant barcode genes (matK and $r b c L$ ) with reduced cost [24]. The same result also found in $M$. tenuiflora, tanin producing trees [8].

Several impurities from secondary metabolites substance, protein, tannins, phenol and polysaccharides often present on stock solution despite some process for elucidate the substance. For standarized dilution for amplification, we tested four dilution ratio, those were 1:10, 1:20, 1:30 and 1:50. Moderate dilution (1:30) produce the best band for our four DNA primer pairs (Fig. 2). At 1:3 dilution, PCR product showed more uniform for all samples. At lower dilutions of DNA (e.g. 1:10, 1:20), the PCR product still unclear and it probably caused by the high concentration of inhibitor enzyme. Another reason was the high proportion of DNA in PCR product so that the free-nucleotides and primer in not sufficient quantity for completing PCR reaction [25].

\section{2. $P C R$ amplification}

Chloroplast and ribosomal-genomic target sequence were selected to test the suitability of genomic DNA extracts for sequence amplification in polymerase chain reactions 


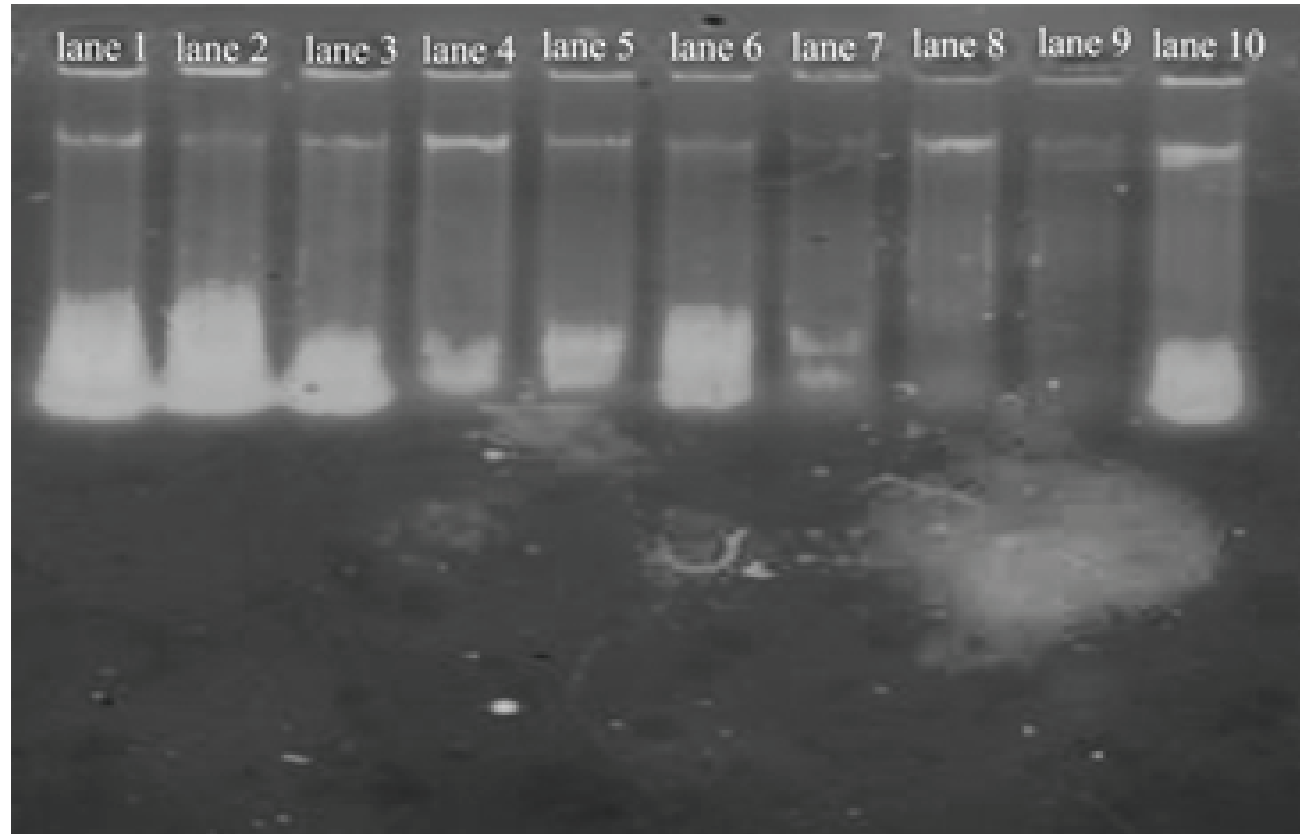

Figure 1: Genomic DNA isolated from individual pasak bumi leaf using CTAB method under 1\% of Agarose Gel.

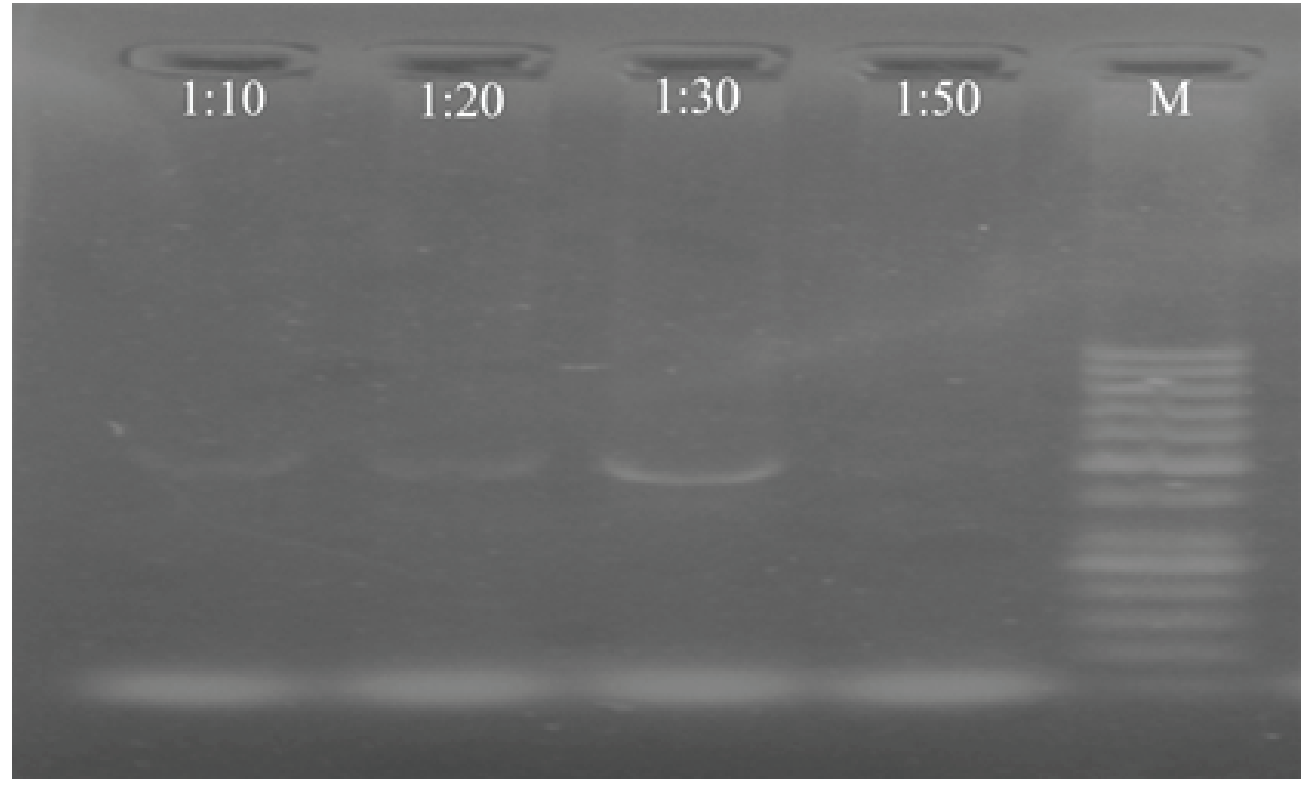

Figure 2: DNA dilutions testing on PCR product.

(PCR). The four selected sequence were ITS, MatK, rbcL and trnL-trnF. In this study, the amplified of PCR product was determined. ITS, $r b c L$ gene and trnL-trnF regions of DNA isolated from pasak bumi were amplified by the PCR reactions (Fig. 3).

ITS, rbcL and matK sequences commonly used for plant barcoding [26, 27] and phylogenetic reconstruction [28]. The ability of primer on DNA amplification on PCR process was determines by primer-template mismatches at the $3^{\prime}$ end of the primer sequence [29]. Our research showed appreciable success in amplification of ITS, rbcL 


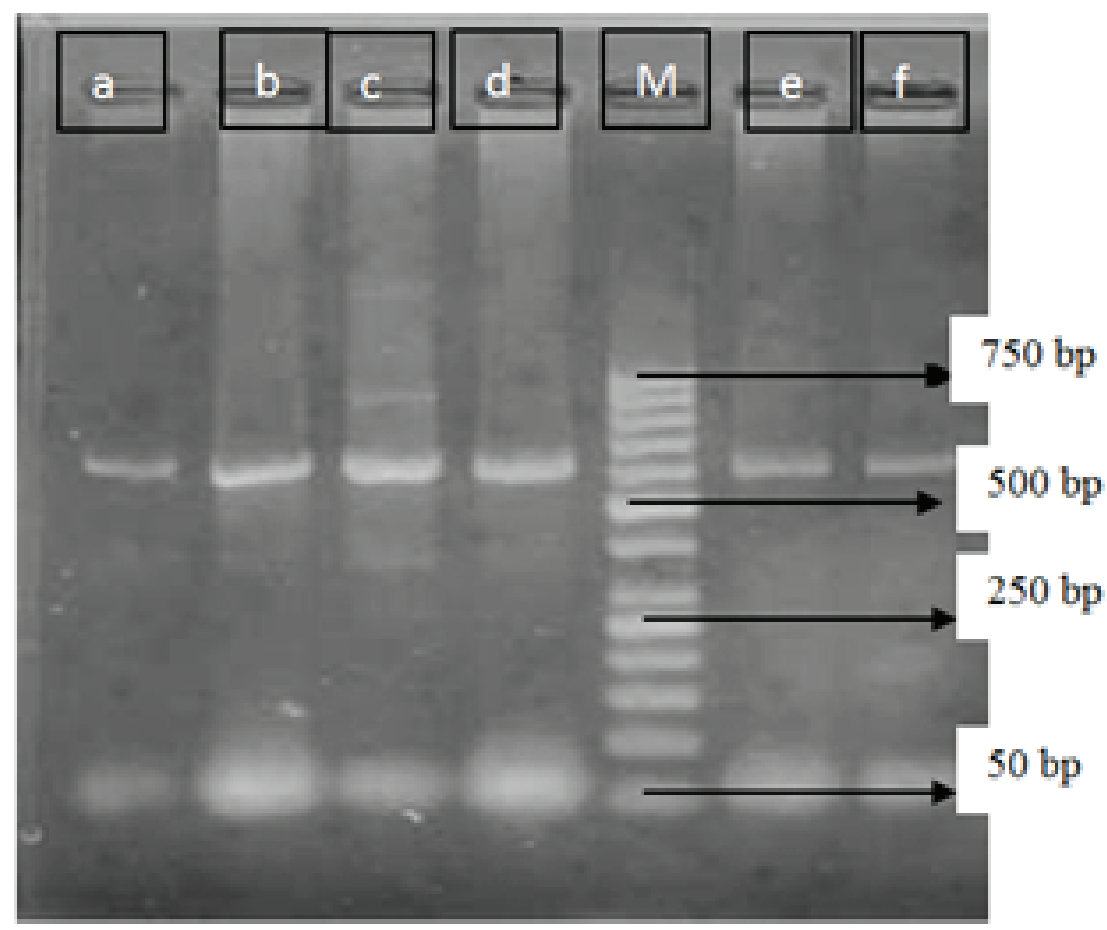

Figure 3: Amplification pattern of $r b c \mathrm{~L}$ annealing $56^{\circ} \mathrm{C}(\mathrm{a}, \mathrm{b}), \quad r b c \mathrm{~L} \mathrm{~T}$ annealing $55^{\circ} \mathrm{C}(\mathrm{c}, \mathrm{d}), \operatorname{trn} \mathrm{L}-\operatorname{trn} \mathrm{F} \mathrm{T}$ annealing $50^{\circ} \mathrm{C}(\mathrm{e}, \mathrm{f})$, M:marker.

gene and trnL-trnF regions. This result was in accordance with [30] which stated that, at in many cases the positive amplification $r b c L$ but negative of matK might be also caused by lower DNA quality and quantity. The other explanation was due to the variation of binding site of matK gene. Similar case also occured in fern using matK sequences [31]. The problem on matK amplification also reported on Styrax in North Sumatra [32]. The successfulness of amplification using trnL-trnF have been reported in previous research for Aquilaria, Styrax sumatrana, Shorea, Taxus sumatrana, and Dipterocarpus [33-37]. Furthermore, Fig. 4, showed good isolation genomic DNA which resulted in good amplification during PCR process would yield good sequence.

\section{Conclussion}

The result showed that CTAB method was able to yield good quality DNA and 30\% dilution produced the best band and further selected for PCR process. PCR amplification found that only ITS, $r b c L$ and $t r n L-t r n F$ confirmed produce the best result and can be utilized for further molecular analysis. 


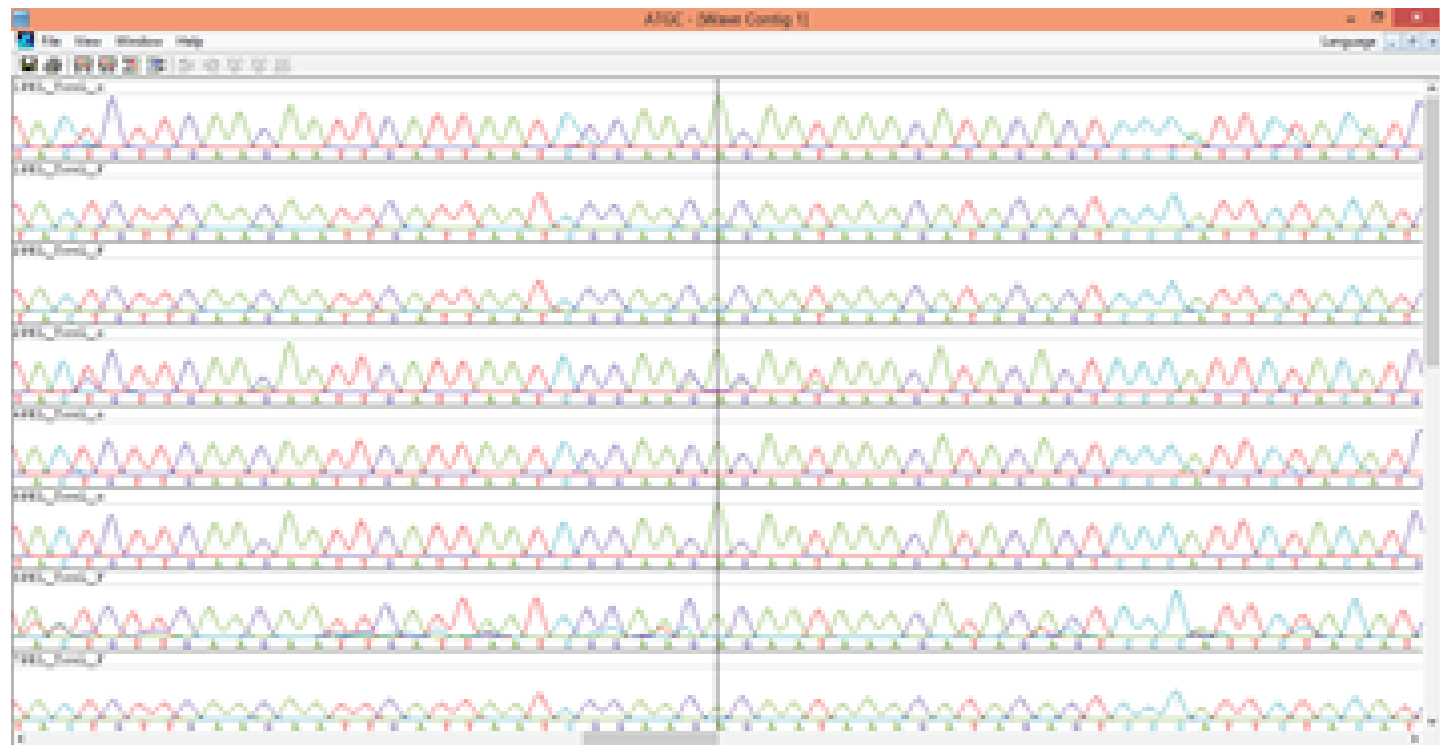

Figure 4: Sequensing result for trnL-trnF region of pasak bumi.

\section{Acknowledgement}

We are grateful to Dr. Fifi Gus Dwiyanti for her laboratory assistance. This work was part of Pasak bumi research funded by TALENTA USU 2018 through the Grant ID2590/UN5.1.R /PPM/2018.

\section{References}

[1] Nurhanan M.Y. et al. (2005). Cytotoxic effects of the root extracts of Eurycoma Longifolia Jack, Phytoter Res. 19 (11), 994-996.

[2] Chan KL et al. (2005). Semisynthetic 15-O-acyl- and 1,15-di-O-acyleurycomanones from Eurycoma longifolia as potential antimalarials, Planta Med. 71(10), 967-969.

[3] Sindelar RD, Walker LA, Sindelar RW, Vangapandu S dan Guo Z. 2005. Biologically active quassinoids and their chemistry: potential leads for drug design, Current Medicinal Chemistry. 12, 173-190.

[4] Nainggolan O. et al (2005). Pengaruh ekstrak etanol akar pasak bumi terhadap perilaku seksual mencit putih, Cermin Dunia Kedokteran 146: 47.

[5] Hussein S. et al. (2005). Multiple shoot formation of important tropical mediclinal plant, Eurycoma longifolia Jack, J.Biotechnol. 22, 349-351

[6] Rosmaina et al. (2003). Genetic Diversity of Eurycoma longifolia Jack based on random amplified polymorphic DNA Marker, JMHT. XIX (2), 138-144. 
[7] Osman A. et al. (2003). Genetic diversity of Eurycoma longifolia inferred from Single Nucleotide Polymorphisms, Plant Physiology. 131, 1294-1301.

[8] Arruda S.R. et al.(2017). An optimized protocol for DNA extraction in plants with a high content of secondary metabolites, based on leaves of Mimosa tenui ora (Willd.) Poir. (Leguminosae), Genetics and Molecular Research. 16 (3).

[9] Kenyon L. et al. (2008). Yams (Dioscorea spp.) from the South Pacific Islands contain many novel badnaviruses: implications for international movement of yam germplasm, Arch. Virol. 153,877-889.

[10] Borges D.B. et al. (2012). Optimization of DNA extraction from fresh leaf tissues of Melanoxylon brauna (Fabaceae), Genet. Mol. Res. 11, 1586-1591.

[11] Olmstead R.G. et al. (1994). Combining data in phylogenetic systematics: an empirical approach using three molecular data sets in the Solanaceae, Syst. Biol. 43, 467-481

[12] Birky C.W. et al. (1995). Uniparental inheritance of mitochondrial and chloroplast genes: Mechanisms and evolution, Proc. Natl Acad. Sci. USA. 92, 11331-11338.

[13] Murray M.G. et al (1980). Rapid isolation of high molecular weight plant DNA. Nucleic Acids Research. 8, 4321-4326.

[14] Levin R.A. et al (2003). Family-level relationships of Onagraceae based on chloroplast rbcL and ndhF data, American Journal of Botany. 90,107-115.

[15] Hao D.C. et al. (2009). Evolution of the chloroplast trnL-trnF region in the gymnosperm lineages Taxaceae and Cephalotaxaceae, Biochem. Genet. 47, 351369

[16] Henry T. et al. (2000). Identification of Aspergillus Species Using Internal Transcribed Spacer Regions 1 and 2, Journal Of Clinical Microbiology. 38(4),1510-1515.

[17] Kuzmina M.L. et al. (2012). Identification of vascular plants of Churchill, Manitoba, using a DNA barcode library, BMC Ecology. 12, 1-11

[18] Pereira J.C. et al. (2011). An efficient method for genomic DNA extraction from different Molluscs Species, International Journal of Molecular Science. 12, 80868095.

[19] Weising, K., Nybom, H.,Wolff, K. and Kahl, G. (2005). DNA Fingerprint in Plant. principles, methods, and applications, 2nd edn, Taylor and Francis Group, 2005. $338 p$

[20] Rehman S.U. et al. (2016). Review on a traditional herbal medicine, Eurycoma longifolia Jack (Tongkat Ali): its traditional herbal medicine, evidence-based pharmacology and toxicology, Molecules. 21:331

[21] Varma A. et al. (2007). Plant genomic DNA isolation: An art or a science, Biotechnology Journal. 2, 386-392 
[22] Moyo M. et al. (2008). Optimising DNA isolation for medicinal plants, South African Journal of Botany. 74, 771-775

[23] Romano E. et al.(1999). Extrac囚a囚o de DNA de plantas: soluc囚o囚es para problemas comumente encontrados, Biotecnologia Cie \ncia \& Desenvolvimento, Brasi $\square$ lia, $\mathbf{9}$, 40-43.

[24] Sahu S.K. et al. (2012). DNA extraction protocol for plants with high levels of secondary metabolites and polysaccharides without using liquid nitrogen and phenol. Inter. Scho. Res. Net, 1-6.

[25] Toader V.A. et al. (2009). Dna isolation and amplification in oak species (quercus spp.)

[26] Asahina H. et al. (2010). Identification of medicinal Dendrobium species by phylogenetic analyses using matK and rbcL sequences, J. Nat. Med, 64, 133-138.

[27] Starr J.R. et al. (2009). Plant DNA barcodes and species resolution in sedges (Carex, Cyperaceae), Molecular ecology resources. 9 (1), 151-163.

[28] Kuo L.Y. et al. (2011). First insights into fern matK phylogeny, Molecular Phylogenetics and Evolution. 59, 556 - 566.

[29] Bru D. et al.(2008). Quantification of the detrimental effect of a single primer-template mismatch by real-time PCR using the 16s rRNA gene as an example, Appl Environ Microbiol, 74, 1660-1663.

[30] Bafeel S.O. et al. (2011). DNA barcoding of arid wild plants using rbcL gene sequences, Genetics and Molecular Research. 11 (3), 1934-1941

[31] . Duffy A.M. et al. (2009). Conservation of selection on matK following an ancient loss of its anking intron, Gene. 438, 17-25.

[32] Susilowati A. et al. (2017). Weak delineation of Styrax species growing in North Sumatra, Indonesia by matK + rbcL gene, Biodiversitas. 18(3), 1270-1274

[33] Lee S.Y. et al. (2016). DNA Barcoding of the endangered Aquilaria (Thymelaeaceae) and its application in species authentication of agarwood products traded in the market. PLoS One. 11: 0154631

[34] Rachmat H.H. et al. (2017). Strong genetic differentiation of the endemic rosinproducing tree Styrax sumatrana (Styracaceae) in North Sumatra, Indonesia, Biodiversitas. 18(4), 1331-1335

[35] Rachmat H.H. et al. (2016). Short Communication: Genetic diversity and conservation strategy considerations for highly valuable medicinal tree of Taxus sumatrana in Indonesia. BIODIVERSITAS. 17 (2) Pages: 487-491. DOI: 10.13057/biodiv/d170213 
[36] Rachmat $\mathrm{HH}$ et al (2012). Contrasting cpDNA variation in two Indonesian endemic lowland dipterocarp species and implications for their conservation. Pak J Biol Sci. 15(16):783-788.37.

[37] Rachmat et al (2012). Genetic diversity, population structure and conservation implication of the endemic Sumatran lowland dipterocarp tree species (Shorea javanica). International Journal of Biodiversity and Conservation. 4(14):573-583. DOI: 10.5897/IJBC12.045 